\title{
Temporal and Spatial Changes in Snow Cover and the Corresponding Radiative Forcing Analysis in Siberia from the 1970s to the 2010s
}

\author{
Lingxue Yu, ${ }^{1}$ Tingxiang Liu, ${ }^{2}$ and Shuwen Zhang ${ }^{1}$ \\ ${ }^{1}$ Northeast Institute of Geography and Agroecology, Chinese Academy of Sciences, Changchun 130012, China \\ ${ }^{2}$ Changchun Normal University, Changchun 130031, China
}

Correspondence should be addressed to Shuwen Zhang; zhangshuwen@neigae.ac.cn

Received 7 October 2016; Revised 4 December 2016; Accepted 19 December 2016; Published 19 February 2017

Academic Editor: Harry D. Kambezidis

Copyright (C) 2017 Lingxue Yu et al. This is an open access article distributed under the Creative Commons Attribution License, which permits unrestricted use, distribution, and reproduction in any medium, provided the original work is properly cited.

\begin{abstract}
In the context of global climate change, the extent of snow cover in Siberia has significantly decreased since the 1970s, especially in spring. The changes of snow cover at middle and high latitudes have significant impacts on the meteorological and hydrological processes because the snow cover can affect the surface energy, water balance, and the development of the atmospheric boundary layer. In this paper, the temporal and spatial changes in snow cover were firstly estimated based on a long time series of remote sensing snow cover data, both showing a decreased trend. Based on this, we estimated the radiative forcing caused by the snow cover changes from the 1970s to the 2010s and compared it with the radiative forcing caused by the vegetation cover changes over the same time period in Siberia, indicating that the snow cover changes in Siberia can accelerate climate warming and the vegetation cover changes here have the opposite effect. Furthermore, the snow cover changes may play a more important role than the vegetation cover changes in regulating the surface radiation balance in Siberia on the regional scale.
\end{abstract}

\section{Introduction}

A large-scale change in snow cover is an indicator of climate change [1]. Snow cover changes can also affect the heat and moisture interactions of the land and atmosphere, as well as the biological phenological characteristics and the ecosystem functions at various scales, due to the radiation characteristics and thermodynamic properties of the snow cover. The temperature record during the 20th and 21st centuries showed that the temperature increased obviously especially from 1970s [2, 3]. In response to climate warming in recent decades, the snow cover extent in Northern Hemisphere has decreased with high confidence especially in spring according to the satellite records [3-7]. The warming and snow cover changes in high latitude terrestrial areas of the Northern Hemisphere represent important energy feedbacks to climate system $[8,9]$. The snow albedo feedback (SAF) examined in 25 climate change simulations, which participate in the Coupled Model Intercomparison Project version 5 (CMIP5) by Qu and Hall [10], indicates that the SAF strength is strongly correlated with the climatological surface albedo when the ground is covered by snow. Furthermore, the snowmelt at middle and high latitudes has significant impacts on meteorological and hydrological processes because they can affect the surface energy, water balance, and the development of the atmospheric boundary layer $[11,12]$. Therefore, accurate monitoring of the changes in snow cover and estimating the climate effects is necessary and essential.

The radiative forcing ( $\mathrm{RF}$ ) concept has been used for many years in the assessments of the Intergovernmental Panel on Climate Change (IPCC) for evaluating and comparing the strengths of the various mechanisms affecting Earth's radiation balance, thereby causing climate change $[13,14]$. Numerous studies used the RF to estimate the climate effects of land cover changes, which focused on the surface albedo and climate feedbacks [13-16]. According to the IPCC 5, the human induced land cover changes, especially the deforestation and agricultural development that occurred in the 20th century, have led to a cooling effect of approximately $-0.15 \mathrm{~W} / \mathrm{m}^{2} \pm 0.1 \mathrm{~W} / \mathrm{m}^{2}$ on the global 
scale [3]. Barnes and Roy calculated the radiative forcing caused by the land use/cover changes for the United States based on the ecoregion scale; the result of the calculation showed a positive surface radiative forcing $0.029 \mathrm{~W} / \mathrm{m}^{2}$ from 1973 to $2000[15,16]$.

Surface albedo is a fundamental parameter in the characterization of terrestrial radiation mechanisms and can influence Earth's radiation balance by controlling the amount of solar radiation absorbed and reflected by land surfaces [17]. Changes in surface albedo depend not only on the type or spatial extent of the changes in land use/cover (which were primarily attributed to seasonal snow cover changes) but also on the interannual snowfall variability [18]. To avoid significant deviations of the estimated radiative forcing due to land cover changes, seasonal vegetation changes were incorporated in the calculation [19]. Note that the seasonal vegetation changes and the surface parameters, such as albedo changes, were largely attributed to seasonal variations in snow, which has a higher albedo and surface emissivity than the land cover types without snow covering $[2,20]$. Compared with seasonal albedo changes, interannual albedo changes are often neglected or considered relatively small [21-24]. However, global warming may have accelerated the decrease in the snow cover extent, especially in boreal regions, thereby causing interannual albedo changes to significantly influence the radiative forcing estimates caused by land cover changes [25]. Barnes and Roy illustrated that radiative forcing estimation is highly sensitive to interannual albedo variability and suggested that future works should model the interannual variations in snow albedo [16].

From another perspective, snow cover is an important component of the cryosphere. Many studies assessed the influence of the cryosphere on Earth's radiation budget at the top of the atmosphere by combining a variety of remote sensing measurements, field measurements, and climate models. Flanner found that the cryospheric cooling declined by $0.45 \mathrm{~W} / \mathrm{m}^{2}$ from 1979 to 2008 , which nearly equaled the contributions from the changes in the land snow cover and sea ice [26]. Perket incorporated a cryosphere radiative effect (CrRE) into two released versions of the Community Earth System Model (CESM1 and CCSM4) to diagnose the shortwave cryosphere radiative effect, which showed that reduced boreal snow cover can help increase the amount of shortwave radiation absorbed globally by $1.4-1.8 \mathrm{~W} / \mathrm{m}^{2}$ in the Representative Concentration Pathway (RCP) 8.5 scenario [27]. However, these studies focused mainly on the snow albedo feedbacks without considering the longwave radiative forcing caused by snow cover changes, which are indispensable and essential in regulating the surface radiation budget.

In this paper, we focused on the seasonal snow cover changes and the corresponding radiative forcing. However, similar to the radiative forcing due to the land cover changes, the global average estimation may hide the strong signals in hot spots regions $[15,28-30]$; therefore, we performed this work on the regional scale. First, the temporal and spatial characteristics of snow cover changes during the period 19702013 in Siberia were analyzed based on remote sensing data.

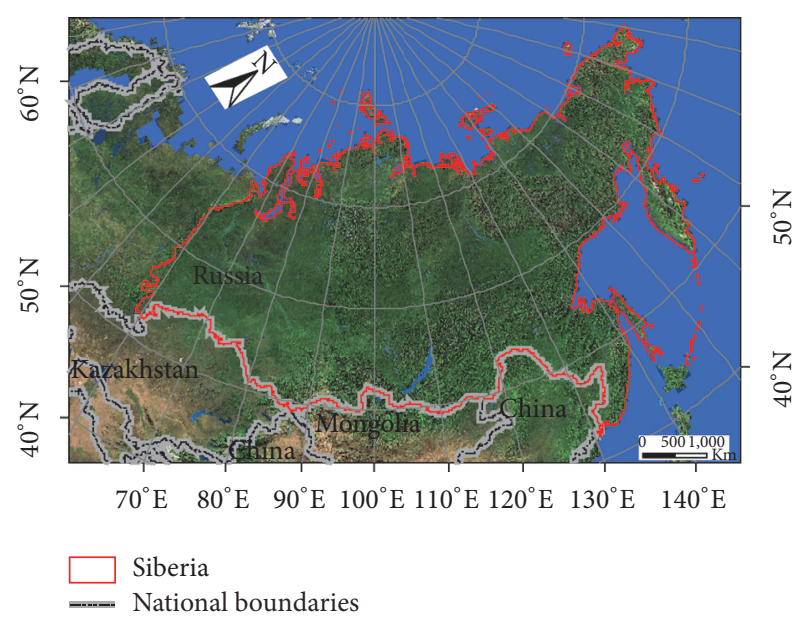

Figure 1: The study area, Siberia.

Next, the seasonal variations in surface albedo and emissivity for each land cover type were extracted, based on which the historical land surface parameters for the study area were reconstructed. Finally, the radiative forcing caused by vegetation cover changes and the snow cover changes were estimated from the 1970s to the 2010s in Siberia.

\section{Study Area and Data Processing}

2.1. Study Area. Siberia covers an area of approximately 12.9 million $\mathrm{km}^{2}$ and extends from the Ural Mountains on the west to the Pacific Ocean on the east, and north to south from the Arctic Ocean to the steppe of Kazakhstan, China, Mongolia, and North Korea (Figure 1). The high latitude of Siberia leads to long cold winters and short mild summers. The continental climate was significant and increased gradually from west to east. The annual average temperature was below $0^{\circ} \mathrm{C}$. The spatial variability in precipitation was significant, with 100 to $250 \mathrm{~mm}$ of rainfall along the Arctic coast, 500 to $600 \mathrm{~mm}$ in the coniferous forest zone, and 1,000 to $2,000 \mathrm{~mm}$ in the Altai Mountains. There are various vegetation types from north to south, including tundra, forest tundra, coniferous forests, and grassland.

In the context of global environmental change, increases in the near surface temperature, deepening of the permafrost active layer depths, shifting of the vegetation zones, and declines in the snow and sea ice extents have made Siberia the focus of attention [31]. Numerous studies have indicated that the global climate change signals in Siberia are pronounced and have already exceeded natural climate variability [32]. In this paper, we will explore the snow cover changes in Siberia over the past 40 years and estimate the corresponding radiative forcing.

2.2. Data. We used two satellite datasets to extract snow cover changes in this study. They were the Northern Hemisphere EASE-Grid 2.0 Weekly Snow Cover and Sea Ice Extent Version 4 product (http://nsidc.org/data/NSIDC-0046) from 1970 to 2013 and the IMS (Interactive Multisensor Snow and 
Ice Mapping System) Daily Northern Hemisphere Snow and Ice Analysis data (http://nsidc.org/data/G02156) from 2004 to 2013.

The EASE-Grid 2.0 dataset is based on the NOAA/NCDC Climate Data Record (CDR) of Northern Hemisphere Snow Cover Extent data derived from the manual interpretation of AVHRR, GOES, and other visible-band satellite data [33], proved to be the longest running satellite-based record of snow cover extent [34]. The data are provided in the polar stereographic projection at a grid cell size of $25 \times 25 \mathrm{~km}$. The temporal coverage is from 3 October, 1966, to 27 December, 2015, with a temporal resolution of 7 days.

The IMS data utilizing a variety of multisourced datasets, like passive microwave, visible imagery, and other ancillary data [33, 35], has been shown to be an effective product for snow applications [36, 37]. The dataset provides snow cover maps for Northern Hemisphere from February 1997 to the present. The formats for this dataset include ASCII text and GeoTIFF in three different resolutions: $1 \mathrm{~km}, 4 \mathrm{~km}$, and $24 \mathrm{~km}$. The data set in $24 \mathrm{~km}$ resolution ranges from 1997 to the present, and the data set in $4 \mathrm{~km}$ and $1 \mathrm{~km}$ resolution range from 2004 and 2014 to present, respectively.

Albedo and surface emissivity data are provided by MCD43B3 (MODIS/Terra+Aqua Albedo 16-Day L3 Global $1 \mathrm{~km}$ SIN Grid V005) and MOD11A2 (MODIS/Terra Land Surface Temperature/Emissivity 8-Day L3 Global $1 \mathrm{~km}$ SIN Grid V005) products from 2004 to 2013 . Note that only pixels with good quality were used in this study. We use the quality assessment (QA) flag to select the best quality pixels in each of the MODIS products. The land cover maps of Siberia in the 1970s and in 2010s are based on the previous work of our research group [38], which were extracted from the global land cover data and the Landsat TM and MSS data through interactive interpretation. All of the products used in the study were transformed to the Albers Equal Area projection at a resolution of $1 \mathrm{~km}$.

Land surface temperature (LST) and shortwave radiation flux (RS) as well as longwave radiation flux (RL) at the surface are provided in $2 / 3^{\circ} \times 1 / 2^{\circ}$ cells from January 1980 to December 2013 by the MERRA (Modern Era Retrospectiveanalysis for Research and Applications) reanalysis dataset (https://disc.sci.gsfc.nasa.gov/daac-bin/FTPSubset.pl). MERRA, which uses a major new version of the Goddard Earth Observing System Data Assimilation System Version 5 (GEOS-5), is a NASA reanalysis of the data for the satellite era, which focuses on historical analyses of the hydrological cycle on a broad range of weather and climate time scales [39]. The tavg1_2d_slv_Nx and tavg1_2d_lnd_Nx products from MERRA with a temporal resolution of 1 hour are used to define mean monthly LST, RS, and RL in watts per meter square $\left(\mathrm{W} / \mathrm{m}^{2}\right)$ for each pixel.

\section{Methods}

3.1. Albedo and Emissivity Calculation. A seasonal variation of the surface albedo for each land cover type exists due to the vegetation phenology and snow conditions. Compared with vegetation growth and demise, whether the land is covered by snow causes the most significant changes in albedo and emissivity. Therefore, in our study, we assume that surface albedo and emissivity at time $t$ on each pixel $\alpha(i, j)_{t}$ and $\varepsilon(i, j)_{t}$ are a function of land cover types $(x)$ and snow conditions $(y)$, while $y$ is a function of time $t$ :

$$
\begin{aligned}
& \alpha(i, j)_{t}=f(x, y), \\
& y=f(t), x \in(0,1,2, \ldots, 16), y \in(0,1) \\
& \varepsilon(i, j)_{t}=g(x, y), \\
& y=g(t), x \in(0,1,2, \ldots, 16), y \in(0,1),
\end{aligned}
$$

where the land cover type $x$ numbered from 0 to 16 corresponds to the land cover classes in IGBP land cover classification system. Snow conditions include 2 statuses, which are snow-covered $(y=1)$ and snow-free $(y=0)$; these statuses vary with time $t$. The one-to-one mapping relationships $(f(x, y)$ and $g(x, y))$ are calculated based on the land cover, albedo, emissivity, and snow cover maps from 2004 to 2013 weekly. Note that $f(x, y)$ and $f(t)$ are unique functions. Using ArcGIS, we can extract the albedo and emissivity changes at each land cover type throughout the year. Next, based on the albedo and emissivity changes and the corresponding snow coverage maps ( 0 or 1 binary maps) throughout the year, we can extract the albedo and emissivity values at each land cover type at any time $t$ pixel by pixel. The monthly average albedo $\alpha(i, j)_{\text {month }}$ and emissivity $\varepsilon(i, j)_{\text {month }}$ can be expressed as

$$
\begin{aligned}
\alpha(i, j)_{\text {month }} & =\sum_{t \in \text { month }} \alpha(i, j)_{t} \\
\varepsilon(i, j)_{\text {month }} & =\sum_{t \in \text { month }} \varepsilon(i, j)_{t} .
\end{aligned}
$$

3.2. Surface Radiative Forcing due to Albedo and Emissivity Change from the 1970s to the 2010s. For each pixel, the monthly surface shortwave radiative forcing $\triangle \mathrm{SRF}(i, j)_{\text {month }}$ due to snow albedo change from the 1970s to the 2010s was estimated as follows:

$$
\begin{aligned}
\Delta \operatorname{SRF}(i, j)_{\text {month }}= & \overline{\mathrm{RS}}_{\text {month }} \\
& \cdot\left(\alpha_{\text {month,2010s }}-\alpha_{\text {month,1970s }}\right),
\end{aligned}
$$

where $\overline{\mathrm{RS}}_{\text {month }}$ is the mean monthly incoming shortwave radiation $\left(\mathrm{W} / \mathrm{m}^{2}\right)$ and $\alpha_{\text {month,2010s }}$ and $\alpha_{\text {month,1970s }}$ are the monthly albedos for the 2010s and the 1970s at each pixel, respectively, defined as in (2). The annual surface shortwave radiative forcing at each pixel $\left(\Delta \operatorname{SRF}(i, j)_{\text {annual }}\right)$ due to the change of snow coverage from the 1970 s to the 2010s was computed as

$$
\Delta \operatorname{SRF}(i, j)_{\text {annual }}=\frac{\sum_{\text {month }=1}^{12} \Delta \operatorname{SRF}(i, j)_{\text {month }}}{12}
$$

where $\Delta \operatorname{SRF}(i, j)_{\text {month }}$ is defined by (4). 


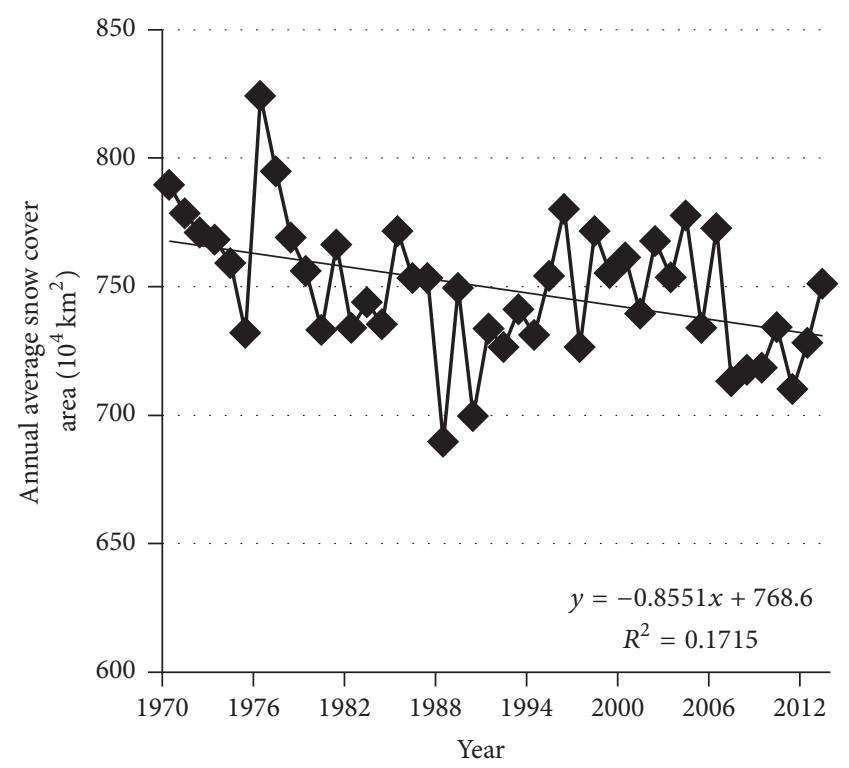

(a)

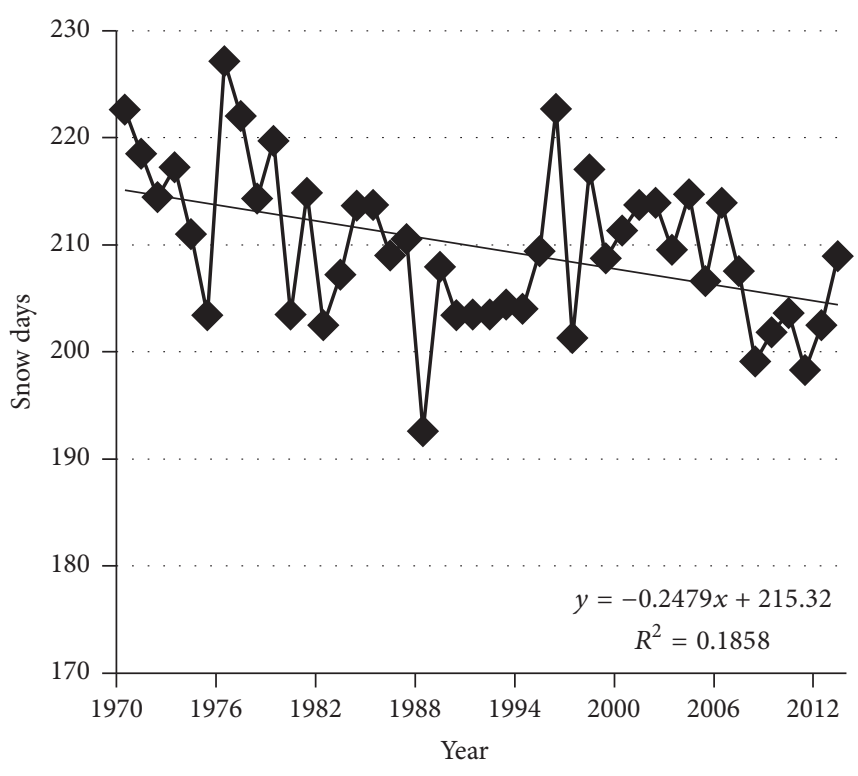

(b)

Figure 2: The annual average snow cover area (a) and snow days (b) from 1970 to 2013.

The monthly surface longwave radiative forcing $\Delta \operatorname{LRF}(i, j)_{\text {month }}$ due to the snow emissivity change from the 1970 s to the 2010 s was estimated as follows:

$$
\begin{aligned}
& \Delta \operatorname{LRF}(i, j)_{\text {month }} \\
&=\left(\overline{\mathrm{RL}}_{\text {month }} \cdot \varepsilon_{\text {month,2010s }}-\sigma \varepsilon_{\text {month,2010s }} \cdot \bar{T}_{\text {month }}^{4}\right) \\
&-\left(\overline{\mathrm{RL}}_{\text {month }} \cdot \varepsilon_{\text {month,1970s }}-\sigma \varepsilon_{\text {month,1970s }} \cdot \bar{T}_{\text {month }}^{4}\right),
\end{aligned}
$$

where $\overline{\mathrm{RL}}_{\text {month }}$ is the mean monthly absorbed longwave radiation $\left(\mathrm{W} / \mathrm{m}^{2}\right), \sigma$ is the Stephen-Boltzmann constant $\left(5.67 \times 10-8 \mathrm{Wm}^{-2} \mathrm{~K}^{-4}\right), \bar{T}_{\text {month }}$ is the mean monthly land surface temperature $(\mathrm{K})$, and $\varepsilon_{\text {month,2010s }}$ and $\varepsilon_{\text {month,1970s }}$ are the monthly emissivities for 2010 s and 1970 s at each pixel, respectively, defined according to (3). The annual surface longwave radiative forcing at each pixel $(\Delta \operatorname{LRF}(i, j)$ annual $)$ due to the change in snow coverage from the 1970s to the 2010 s was computed as

$$
\Delta \operatorname{LRF}(i, j)_{\text {annual }}=\frac{\sum_{\text {month }=1}^{12} \Delta \operatorname{LRF}(i, j)_{\text {month }}}{12},
$$

where $\Delta \operatorname{LRF}(i, j)_{\text {month }}$ is defined by (6).

\section{Results}

4.1. The Changes in Snow Cover from 1970s to 2010s. Based on a long time series of remote sensing snow cover data (EASE-Grid 2.0 Weekly Snow Cover) for the last 44 years (1970-2013), the annual average snow cover area and snow days information are obtained (Figure 2). The average snow area and snow days in Siberia remained between 700 and 800 million square kilometers and 210 days, respectively. In addition, the average snow coverage and snow days showed a decreasing trend of $-0.855 * 10^{4} \mathrm{~km}^{2} / \mathrm{a}$ and $-0.248 \mathrm{~d} / \mathrm{a}$, respectively, both of which are statistically significant at $95 \%$ confidence level.

Taking into account the climatic conditions of the study area with cold winters and mild summers, the snow cover area variation mainly occurred in spring due to the increasing temperatures, which could lead to earlier snowmelt. To clarify the change in snow cover extent during the past 44 years more clearly, as an example, we selected the snow cover extent variation in spring and autumn, which are when the snow starts to melt and fall over a large range, to analyze the change in its spatial pattern. The average snow extent in spring and autumn during 1970-2013 and during 2009 to 2013 was shown in Figure 3.

Figure 3 illustrates the average snow cover extent in spring and autumn during 1970 to 2013 as well as during 2009 to 2013. In spring, the average snow cover extent of the past five years shrank back toward the polar circle with the snow line retreated to between $60^{\circ} \mathrm{N}$ and $70^{\circ} \mathrm{N}$. Through the overlay analysis of the snow cover extent during the two periods, we estimated that the average snow cover area in spring decreased from 6.6 to 5.5 million square kilometers, which accounted for approximately $8.5 \%$ of the area of Siberia. In autumn, the variation in snow cover changes was not as obvious as in spring. The average snow cover area decreased about 0.18 million square kilometers.

To the snow days, we used a \% variations described by Kambezidisa et al. (2016) [39] to represent the percentage differences in snow days over Siberia during 1970 to 2013. the percentage differences $\%$ is calculated as $(\%)=\mathrm{a} * 44 /$ "mean" $* 100$, where a is the slope of the linear regression in snow days from 1970 to 2013, 44 is the number of years during the studied period and "mean" is the average of snow days during 


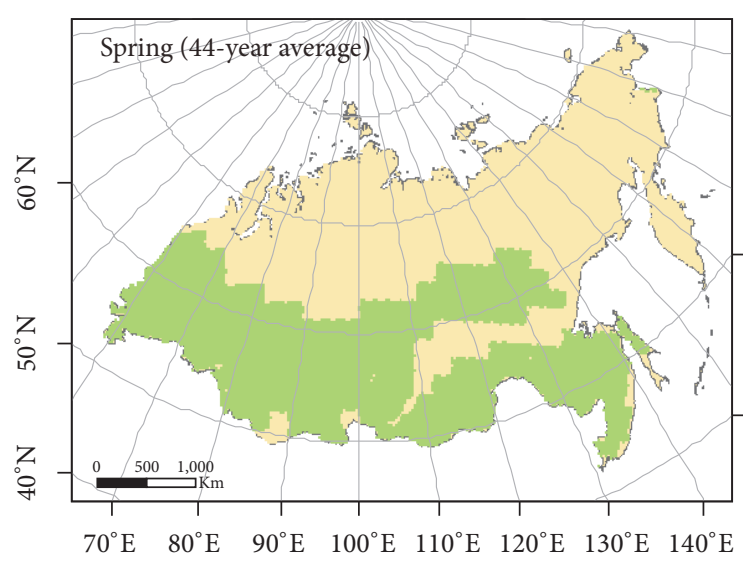

$\square$ Snow-free Snow

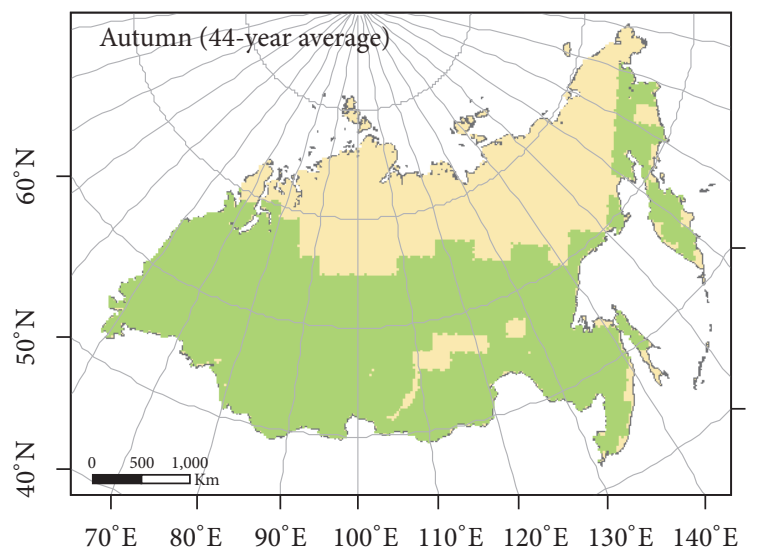

Snow-free Snow

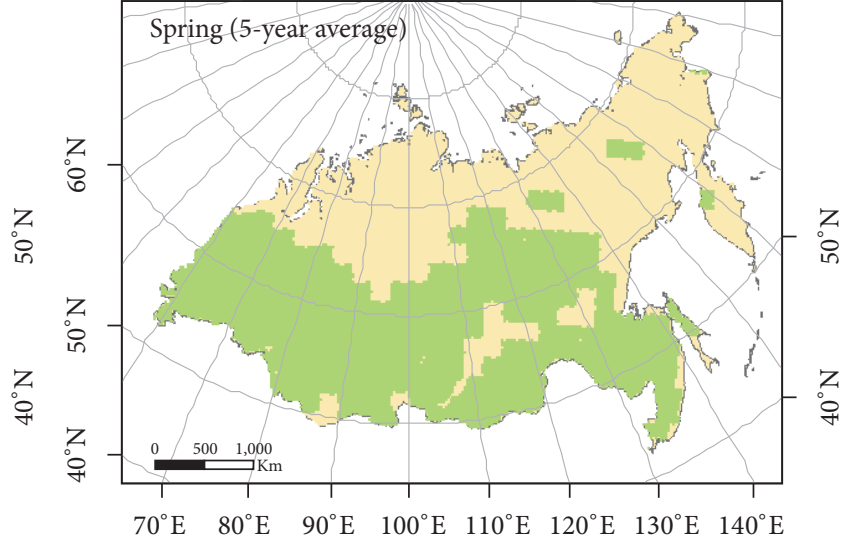

Snow-free

Snow

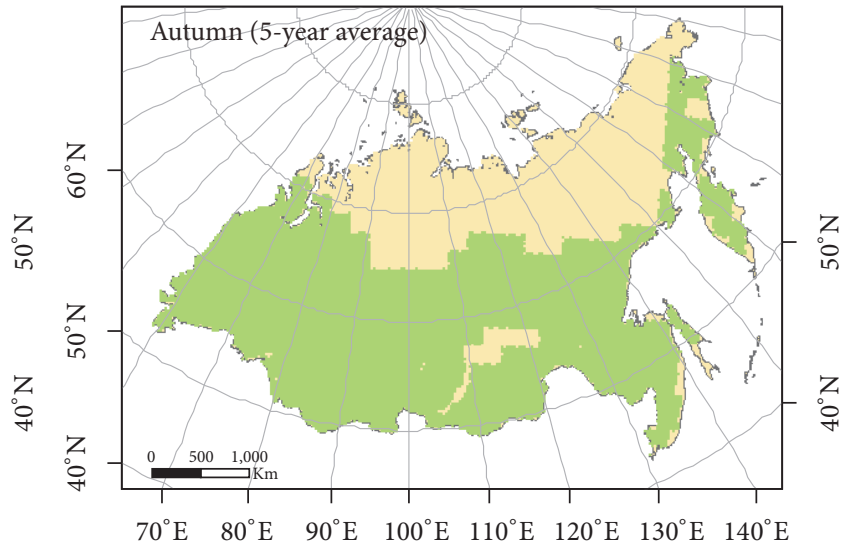

Snow-free

Snow

FIGURE 3: The average snow cover extent in spring and autumn from 1970 to 2013 and from 2009 to 2013.

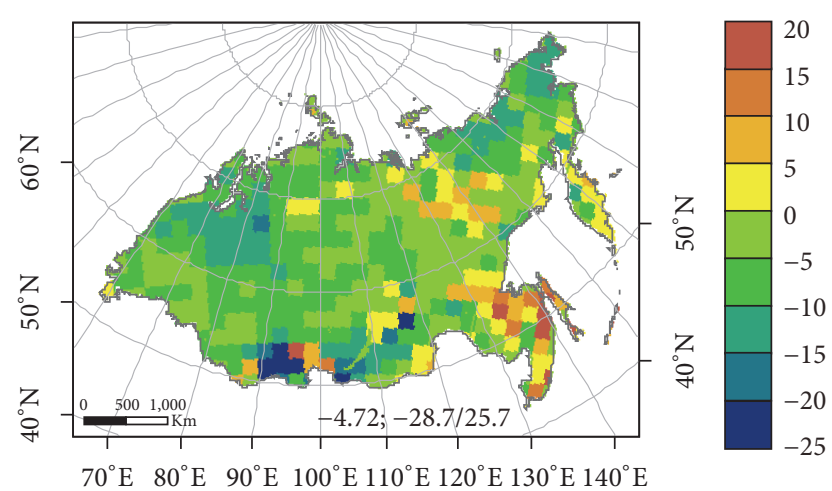

FIGURE 4: The spatial distribution of the (\%) variations in snow days from 1970 to 2013 . The spatially averaged (\%) variations along with the minimum/maximum (\%) variations over the study area are also shown.

1970 to 2013 . The spatial distribution of the (\%) variations in snow days was shown in Figure 4.
Figure 4 illustrates the spatial distribution of the variations in snow days during 1970 to 2013 . The (\%) variations in snow days exhibited a large spatial heterogeneity in the study area. Overall, the number of snow days showed a decreased trend in Siberia. The spatially averaged (\%) variation was $-4.72 \%$, with the maximum and minimum (\%) variations being $25.7 \%$ and $-28.7 \%$, respectively. The maximum value appeared at the northeast of Heilongjiang Basin while the minimum value appeared at the southernmost part of Siberia. This may be attributed to the local climatic conditions.

4.2. Albedo and Emissivity Change Caused by Snow Cover. Surface albedo is mainly dominated by the land surface properties, such as land cover types and snow conditions. The variation of albedo among different vegetation types is well known and widely accepted [2]. However, the seasonal changes in albedo should be given more attention, considering that the seasonal variation of surface albedo is comparable or even more than the albedo difference between vegetation types. The surface emissivity is another critical surface parameter that can influence the surface longwave 


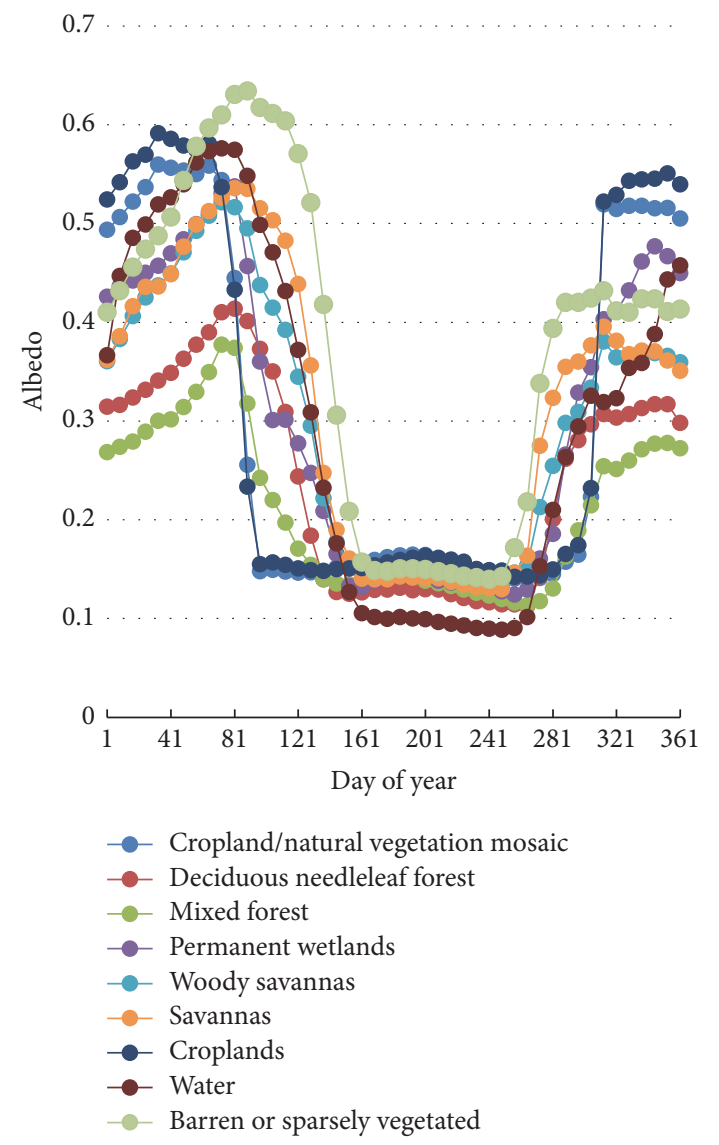

(a)

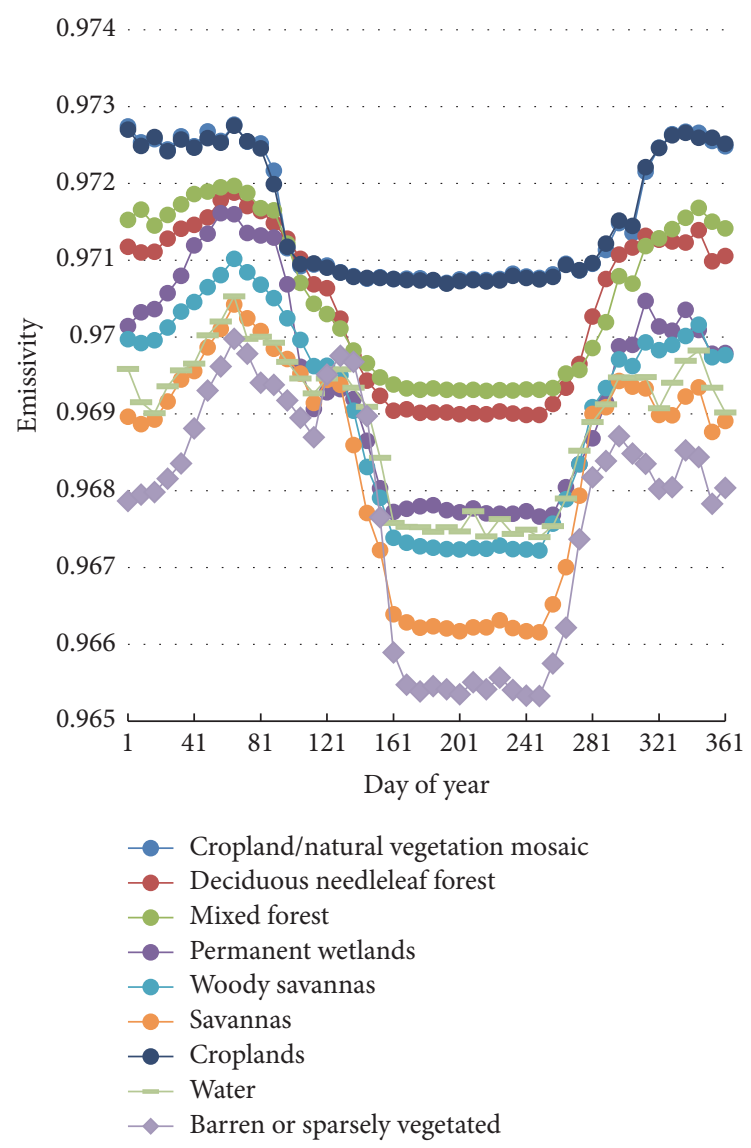

(b)

FIgURE 5: The average albedo (a) and emissivity (b) of each land cover class throughout the year in Siberia.

radiation flux. In contrast to albedo, although very important in the radiation balance, the surface emissivity has not received much attention [12]. However, similar to albedo, the surface emissivity not only changes among land cover types but also varies with time. Based on the MCD43B3 albedo and MOD11A2 emissivity data with good quality, we calculated the albedo and emissivities for the 9 main land cover types in Siberia every eight days in 2010 (Figure 5).

Figure 5(a) shows that all of the land cover types exhibit a similar pattern, with higher albedo values in the snowcovered winter months and lower values in the snow-free summer months. Generally, the regional average albedo of each land cover type in Siberia reached its maximum in January and February, when the study area was completely covered by snow. In July and August, the albedo dropped to its lowest value because the snow in Siberia had melted at this time. Furthermore, a gradual change instead of a sudden change in albedo occurred in the spring and autumn seasons, which was due to the snowmelt and snowfall being asynchronous in the region. As the study area is near the Arctic Circle, the polar nights lead to the peak value that happened between days 81 and 121 .

Figure 5(b) shows that the emissivities of all land cover types exhibit a similar pattern, with higher values in the snowcovered winter months and lower values in the snow-free summer months, which is in general agreement with that shown for albedo. Generally, the pattern throughout the year was that the regional average emissivity of each land cover type in Siberia reached its maximum in January and February, whereas it reached a minimum in July and August. For the same reason, a gradual change in emissivity existed in the spring and autumn seasons. The emissivity of all the land cover types showed similar trends to those of the albedo. However, compared with the surface albedo, the differences of the surface emissivities among the land cover types and between the snow-covered and snow-free conditions were relatively small.

Although all the land cover types showed similar albedo variation, the variations in albedo and emissivity between the different land cover types were obvious, in both snow-covered and snow-free seasons. To distinguish these differences and obtain an accurate surface albedo and emissivity value for each land cover class throughout the year, we calculated the means and standard deviations of the white sky albedo and emissivity for each land cover class under both snow and snow-free conditions (Table 1), based on the land cover maps, the snow cover maps (IMS), the MODIS broadband white sky albedo data, and MODIS emissivity data from 2004 to 2013.

Table 1 summarizes the MODIS 15-year mean snow and snow-free albedos and emissivity for each land cover 
TABLE 1: Means and standard deviations (SD) of the snow-free (SF) and snow-covered (SC) white sky albedos and emissivities for each land cover class.

\begin{tabular}{lcccccccc}
\hline Land cover type & Albedo (SF) & SD & Albedo (SC) & SD & Emissivity (SF) & SD & Emissivity (SC) & SD \\
\hline Evergreen needleleaf forest & 0.139 & 0.008 & 0.329 & 0.033 & 0.9696 & $1.37 E-05$ & 0.9720 & $1.86 E-04$ \\
Deciduous needleleaf forest & 0.126 & 0.005 & 0.336 & 0.033 & 0.9690 & $1.49 E-05$ & 0.9714 & $2.66 E-04$ \\
Deciduous broadleaf forest & 0.157 & 0.008 & 0.390 & 0.046 & 0.9685 & $3.82 E-05$ & 0.9712 & $2.34 E-04$ \\
Mixed forest & 0.136 & 0.007 & 0.293 & 0.033 & 0.9693 & $1.02 E-05$ & 0.9716 & $2.15 E-04$ \\
Open shrublands & 0.140 & 0.004 & 0.403 & 0.090 & 0.9661 & $1.42 E-04$ & 0.9685 & $4.18 E-04$ \\
Woody savannas & 0.144 & 0.005 & 0.416 & 0.058 & 0.9673 & $1.68 E-05$ & 0.9702 & $4.16 E-04$ \\
Savannas & 0.138 & 0.004 & 0.419 & 0.060 & 0.9662 & $4.40 E-05$ & 0.9694 & $5.33 E-04$ \\
Grasslands & 0.154 & 0.005 & 0.502 & 0.024 & 0.9695 & $1.60 E-05$ & 0.9720 & $1.82 E-04$ \\
Permanent wetlands & 0.140 & 0.004 & 0.463 & 0.030 & 0.9677 & $4.21 E-05$ & 0.9706 & $6.32 E-04$ \\
Croplands & 0.159 & 0.004 & 0.556 & 0.021 & 0.9707 & $3.06 E-05$ & 0.9726 & $9.01 E-05$ \\
Urban and built-up & 0.140 & 0.005 & 0.405 & 0.016 & 0.9690 & $2.85 E-05$ & 0.9716 & $2.01 E-04$ \\
Cropland/natural vegetation mosaic & 0.160 & 0.005 & 0.529 & 0.022 & 0.9708 & $3.51 E-05$ & 0.9726 & $9.81 E-05$ \\
Snow and ice & $*$ & $*$ & 0.673 & 0.030 & $*$ & $*$ & 0.9688 & $3.84 E-04$ \\
Barren or sparsely vegetated & 0.147 & 0.004 & 0.474 & 0.072 & 0.9654 & $7.19 E-05$ & 0.9685 & $7.31 E-04$ \\
Water & 0.097 & 0.004 & 0.464 & 0.079 & 0.9675 & $1.17 E-04$ & 0.9696 & $4.43 E-04$ \\
\hline
\end{tabular}

TABLE 2: The monthly radiative forcing caused by snow cover changes $\left(\mathrm{W} / \mathrm{m}^{2}\right)$.

\begin{tabular}{lcccccc}
\hline RF/month & 1 & 2 & 3 & 4 & 5 & 6 \\
RFS & 0 & 0 & -0.12732 & 0.08991 & 13.10830 & 16.92410 \\
RFL & 0 & 0 & -0.00041 & 0.00052 & 0.03666 & 0.04947 \\
\hline RF/month & 7 & 8 & 9 & 10 & 11 & 12 \\
RFS & 3.25442 & 0.02688 & -1.37446 & -1.40368 & 0.64019 & -0.00834 \\
RFL & 0.00984 & 0.00008 & -0.00749 & -0.00984 & 0.00516 \\
\hline
\end{tabular}

type. The snow-free mean albedo values summarized in Table 1 were comparable to those of Zhou et al. (2003) [40] and Myhre et al. (2005) [41]. The snow albedo values are comparable to those described by Barnes and Roy (2010) [16]. Cropland and grassland have the highest snow and snowfree albedos, while forests and water have the lowest snow albedos and snow-free albedos, respectively. The albedos of vegetation surfaces with high canopy densities increased the least when the surface transformed from snow-free to snowcovered, while the albedos of the surfaces with barren or short vegetation increased the most. The land cover types with the greatest differences between snow and snow-free albedo values are croplands and cropland/natural vegetation mosaic, which correspond to differences of 0.397 and 0.369 , respectively. The forest classes, which mainly include deciduous needleleaf forest and mixed forest, have relative small differences of 0.210 and 0.157 , respectively; the small differences were mainly caused by snow being hidden by the forest canopy.

Concerning the emissivity, the croplands and cropland/natural vegetation have the highest snow-free and snowcovered values, while the savannas and permanent wetlands have the lowest values. The land cover types with the greatest differences between snow-covered and snow-free emissivity are savannas and barren or sparsely vegetated, which have differences of 0.0031 , with the smallest differences of 0.0018 found in the croplands and cropland/natural vegetation mosaic classes.

\subsection{Surface Radiative Forcing Caused by Snow Cover Changes} from the 1970s to the 2010s. In this section, we discuss the surface radiative forcing caused by the change in snow cover extent from the 1970s to the 2010s without considering the radiative forcing caused by the land cover changes not including snow changes. Under the assumption that the land cover in Siberia from the 1970s to the 2010s remained unchanged, the land cover map in 2010 was used as the control layer to calculate the monthly and annual surface radiative forcing due to the snow cover changes from the 1970 s to the 2010s (Table 2). Note that the snow cover extents of the 1970s and the 2010s were derived from the snow cover extent data from 1970 to 1979 and 2004 to 2013, respectively, through a weighted average based on the EASE-Grid 2.0 Weekly Snow Cover dataset. In this way, we can effectively reduce or eliminate the impacts of the interannual variability and snow cover outliers on the estimation results.

According to Table 2, the RFS and RFL caused by the snow cover changes exhibit the same sign during the 12 months. In the winter months, such as January and February, the RFS and RFL were zero, which means that 


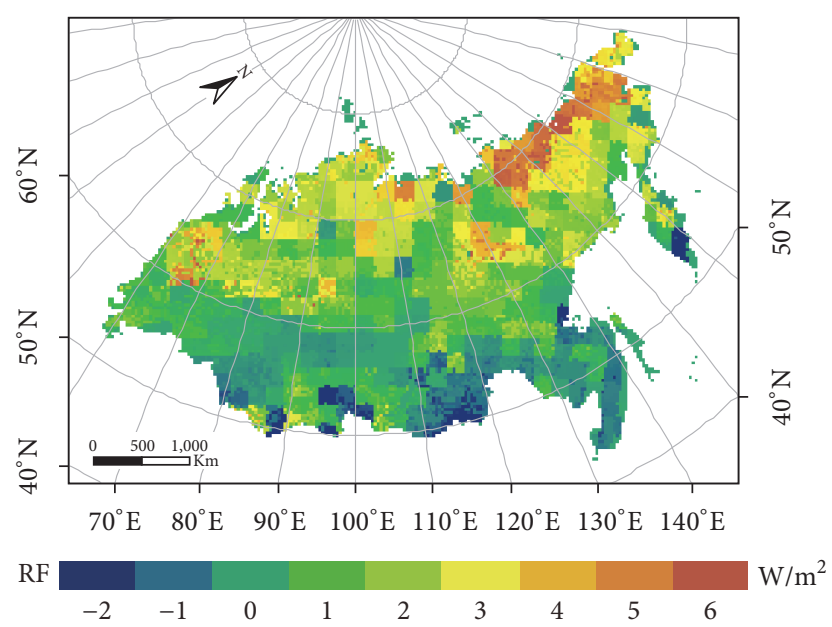

FIGURE 6: The annual NRF caused by the snow cover changes from the 1970 s to the 2010 s.

the snow cover extent in these months was unchanged. In the main snow melt months, such as June, the RFS and RFL reached their maximum values of $16.924 \mathrm{~W} / \mathrm{m}^{2}$ and $0.049 \mathrm{~W} / \mathrm{m}^{2}$, respectively, which were due to the reduction in the snow coverage. The autumn months, such as September and October, showed negative RF values, which indicate that the snow cover increased during the period from the 1970s to the 2010s. However, the RFS caused by albedo changes were significantly higher than the RFL caused by emissivity, with the RFS ranges from $-1.40 \mathrm{~W} / \mathrm{m}^{2}$ to $13.11 \mathrm{~W} / \mathrm{m}^{2}$, while the RFL varies from $-0.0098 \mathrm{~W} / \mathrm{m}^{2}$ to $0.037 \mathrm{~W} / \mathrm{m}^{2}$. Furthermore, the annual net radiative forcing caused by snow cover changes was $2.60 \mathrm{~W} / \mathrm{m}^{2}$, in which the albedo effect was dominant, with a $99.61 \%$ contribution. In other words, the albedo effects played a more crucial role than the emissivity effects in regulating the surface radiation budget.

The annual NRF caused by the snow cover changes from the 1970s to the 2010s was averaged based on the NRF layers from the 12 months of the year (Figure 6).

From the 1970s to the 2010s, the NRF in most of the regions was positive. The NRF increases with increasing latitude. At latitudes higher than $60^{\circ} \mathrm{N}$, where the snow cover varies significantly, the NRF was higher than $2 \mathrm{~W} / \mathrm{m}^{2}$, which contributed to the balance between the snow cover shrinking in spring and the snow cover extension in autumn from the 1970 s to the $2010 \mathrm{~s}$. At latitudes close to $50^{\circ} \mathrm{N}$, the NRF was near zero, or even negative, indicating that the snow cover changes in these areas lead to a cooling effect. Nevertheless, the warming effects in high latitudes regions were stronger than the cooling effects at the lower latitudes, which eventually led to the regional warming effect. From this perspective, the studies that ignored the interannual snow cover changes and the corresponding albedo and emissivity changes may underestimate the importance of the land cover changes in the radiative forcing. In order to explain the position of snow cover changes in regulating regional

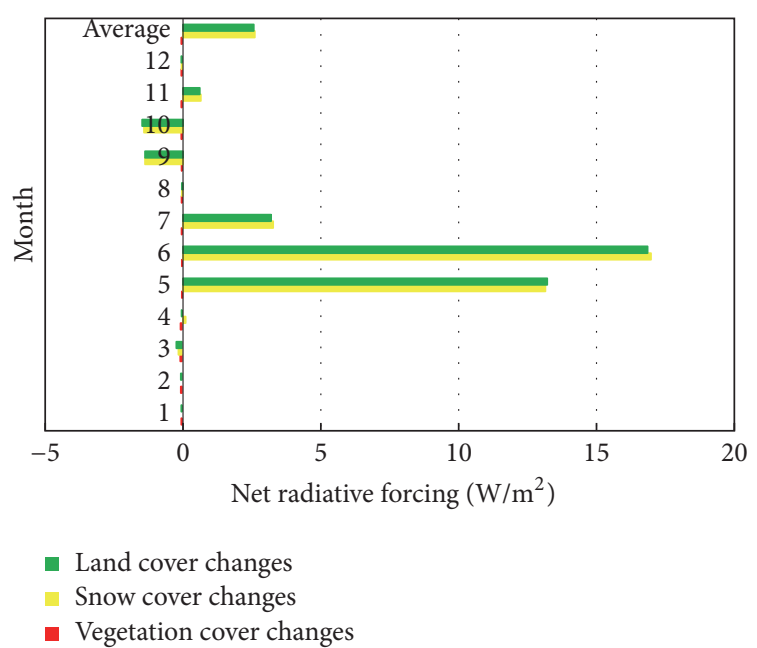

FIgURE 7: The monthly and annual NRF in Siberia from the 1970s to the 2010s.

radiation balance, we will evaluate and compare the effect caused by the snow cover changes and the land cover changes in the next section.

\section{RF due to Land Cover Changes}

In this section, the monthly and annual radiative forcing caused by the land cover changes and vegetation cover changes were estimated and compared with that caused by the snow cover changes. When we calculated the radiative forcing caused by vegetation cover changes, we considered that there is no interannual variation of snow cover, and vice versa. The estimation results were shown in Figure 7.

In Figure 7, we observe that the NRF caused by the vegetation cover changes was negative, with the absolute value less than $0.1 \mathrm{~W} / \mathrm{m}^{2}$, while the NRF caused by the snow cover changes were larger numerically, with obvious seasonal variations. In the snowmelt months, such as May and June, the NRF caused by the snow cover changes were higher than $10 \mathrm{~W} / \mathrm{m}^{2}$, indicating serious warming effects. In snowfall months, such as September or October, the NRF was negative, ranging from -1.5 to $-1.3 \mathrm{~W} / \mathrm{m}^{2}$, which represents a cooling effect. The NRF is relatively small in the winter months and the summer months, when the snow cover extent was stable. The differences in the NRF in the 12 months of the year can reflect the interannual snow cover changes; that is, during the 1970 s to the 2010s, the extent of the snow cover shrinking in the snowmelt months was more intensive than the extent of snow cover expansion in the snowfall months. Overall, from the 1970 s to the 2010s, the radiative forcing caused by the land cover changes including vegetation cover and snow cover changes was $2.56 \mathrm{~W} / \mathrm{m}^{2}$, which were close to the effects due to the snow cover changes. The results also can further indicate the dominant role that snow cover plays in the radiative forcing of the climate system in Siberia.

The radiative forcing reported in IPCC5 was estimated on the global scale from the 1750 s to 2011 . The 
radiative forcing caused by the land cover changes was $-0.15 \mathrm{~W} / \mathrm{m}^{2} \pm 0.1 \mathrm{~W} / \mathrm{m}^{2}$, which corresponds to a cooling effect globally (IPCC, 2013). In Siberia, where the land cover was less influenced by human beings, the radiative forcing due to the land cover changes was $2.56 \mathrm{~W} / \mathrm{m}^{2}$ from the 1970 s to the 2010s. Although we cannot compare our results with the global average value at the same time level, we can conclude that the impacts of the land cover changes in Siberia on the radiation budget from the 1970s to the 2010s were extremely huge.

To better assess the impacts of the land cover changes on the surface radiation budget, the time series should be extended to a century or longer, which can help avoid the effects of small cycle changes in the climate system on the research findings. This is what we want to do in our further study.

\section{Conclusions}

Compared with the radiative forcing assessment methods based on ecoregions, our works devoted greater attention to the interannual variability of albedo and emissivity caused by the snow cover changes instead of only averaging the albedo data of each land cover types in each of the ecoregions month by month. This process can improve our understanding of the significance of the snow cover changes on the radiation balance and even the climate feedbacks.

The land cover maps, IMS snow cover datasets, and the MODIS surface data were used to capture the seasonal variations of the surface parameters for each land cover type. The statistics demonstrated that the snow cover can greatly influence the albedo and emissivity. The albedo and emissivity changes caused by the snow cover changes can be as much as or even greater than the changes due to the conversion between vegetation cover types. This result explains why we should pay attention to the interannual snow cover changes and the radiative forcing.

The radiative forcing caused by the snow cover changes were estimated for each pixel according to the assessment equation. As a result, the NRF caused by the snow cover changes was found to be $2.6 \mathrm{~W} / \mathrm{m}^{2}$, which shows a warming effect, from the 1970s to the 2010s in Siberia. Compared with the snow cover changes, the NRF caused by the vegetation cover changes was $-0.0179 \mathrm{~W} / \mathrm{m}^{2}$, indicating a cooling effect. The integrated NRF caused by the land cover changes including the vegetation cover changes and the snow cover changes was $2.56 \mathrm{~W} / \mathrm{m}^{2}$, which shows a similar value to the NRF caused by the snow cover changes. In other words, the interannual snow cover changes were more important in regulating the surface radiation balance than the vegetation cover changes in Siberia from the 1970s to the 2010s. The results also showed that the shortwave radiative forcing due to albedo changes was greater than the longwave radiative forcing due to emissivity changes; that is, the albedo feedbacks were stronger than the emissivity feedbacks regarding the effect on the surface radiation budget.
In the future, if the snow cover extent continues to decrease in Siberia, the regional climate will be increasingly warmer as the feedbacks between climate and snow cover are mutually promoting. In this way, the cumulative warming feedback can largely influence the vegetation phenology, which may result in the northern edge of the forest moving northward to replace savannas. Consequently, the climate effects of this warming would be the same as the afforestation in the boreal areas. The combination of the snow cover changes and the natural vegetation cover changes greatly accelerates climate warming. Therefore, the snow cover changes and their radiative forcing warrant further investigation to respond to the challenge of global warming.

\section{Competing Interests}

The authors declare that they have no competing interests.

\section{Acknowledgments}

This study was supported by the "Strategic Priority Research Program-Climate Change: Carbon Budget and Relevant Issues" of the Chinese Academy of Sciences (no. XDA05090310) and the National Program on Key Basic Research Project (973 program) (no. 2010 CB950901-2-1).

\section{References}

[1] R. D. Brown and P. W. Mote, "The response of Northern Hemisphere snow cover to a changing climate," Journal of Climate, vol. 22, no. 8, pp. 2124-2145, 2009.

[2] E. S. Euskirchen, A. D. Mcguire, and F. S. Chapin, "Energy feedbacks of northern high-latitude ecosystems to the climate system due to reduced snow cover during 20th century warming," Global Change Biology, vol. 13, no. 11, pp. 2425-2438, 2007.

[3] IPCC, Climate Change, 2013. The Physical Science Basis, Cambridge University Press, Cambridge, UK, 2013.

[4] P. Y. Groisman, T. R. Karl, and R. W. Knight, "Observed impact of snow cover on the heat balance and the rise of continental spring temperatures," Science, vol. 263, no. 5144, pp. 198-200, 1994.

[5] R. D. Brown, "Northern Hemisphere snow cover variability and change, 1915-97," Journal of Climate, vol. 13, no. 13, pp. 23392355,2000

[6] D. G. Dye, "Variability and trends in the annual snow-cover cycle in Northern Hemisphere land areas, 1972-2000," Hydrological Processes, vol. 16, no. 15, pp. 3065-3077, 2002.

[7] R. D. Brown and D. A. Robinson, "Northern Hemisphere spring snow cover variability and change over 1922-2010 including an assessment of uncertainty," Cryosphere, vol. 5, no. 1, pp. 219-229, 2011.

[8] S. J. Déry and R. D. Brown, "Recent Northern Hemisphere snow cover extent trends and implications for the snow-albedo feedback," Geophysical Research Letters, vol. 34, no. 22, Article ID L22504, 2007.

[9] A. J. Dietz, C. Kuenzer, and C. Conrad, "Snow-cover variability in central Asia between 2000 and 2011 derived from improved MODIS daily snow-cover products," International Journal of Remote Sensing, vol. 34, no. 11, pp. 3879-3902, 2013. 
[10] X. Qu and A. Hall, "On the persistent spread in snow-albedo feedback," Climate Dynamics, vol. 42, no. 1-2, pp. 69-81, 2014.

[11] D. E. Petzold, "An estimation technique for net longwave and net radiation over snow at Toronto, Goose Bay and Resolute, Canada," Archiv für Meteorologie, Geophysik und Bioklimatologie Serie B, vol. 28, no. 1-2, pp. 73-90, 1980.

[12] J. E. Sicart, J. W. Pomeroy, R. L. H. Essery, and D. Bewley, "Incoming longwave radiation to melting snow: observations, sensitivity and estimation in northern environments," Hydrological Processes, vol. 20, no. 17, pp. 3697-3708, 2006.

[13] J. Hansen, M. Sato, and R. Ruedy, "Radiative forcing and climate response," Journal of Geophysical Research Atmospheres, vol. 102, no. 6, pp. 6831-6864, 1997.

[14] E. L. Davin, N. de Noblet-Ducoudré, and P. Friedlingstein, "Impact of land cover change on surface climate: relevance of the radiative forcing concept," Geophysical Research Letters, vol. 34, no. 13, 2007.

[15] C. A. Barnes and D. P. Roy, "Radiative forcing over the conterminous United States due to contemporary land cover land use albedo change," Geophysical Research Letters, vol. 35, no. 9, 2008.

[16] C. A. Barnes and D. P. Roy, "Radiative forcing over the conterminous United States due to contemporary land cover land use change and sensitivity to snow and interannual albedo variability," Journal of Geophysical Research: Biogeosciences, vol. 115, no. 4, 2010.

[17] R. E. Dickinson, "Land processes in climate models," Remote Sensing of Environment, vol. 51, no. 1, pp. 27-38, 1995.

[18] Y. Jin, C. B. Schaaf, F. Gao et al., "How does snow impact the albedo of vegetated land surfaces as analyzed with MODIS data?" Geophysical Research Letters, vol. 29, no. 10, pp. 12-1-12-4, 2002.

[19] U. S. Nair, D. K. Ray, J. Wang et al., "Observational estimates of radiative forcing due to land use change in southwest Australia," Journal of Geophysical Research Atmospheres, vol. 112, no. 9, Article ID D09117, 2007.

[20] R. A. Betts, "Offset of the potential carbon sink from boreal forestation by decreases in surface albedo," Nature, vol. 408, no. 6809, pp. 187-190, 2000.

[21] Y. Jin, C. B. Schaaf, C. E. Woodcock et al., "Consistency of MODIS surface bidirectional reflectance distribution function and albedo retrievals: 1. Validation," Journal of Geophysical Research D: Atmospheres, vol. 108, no. 5, 2003.

[22] Z. Wang, X. Zeng, M. Barlage, R. E. Dickinson, F. Gao, and C. B. Schaaf, "Using MODIS BRDF and albedo data to evaluate global model land surface albedo," Journal of Hydrometeorology, vol. 5, no. 1, pp. 3-14, 2004.

[23] F. Gao, C. B. Schaaf, A. H. Strahler, A. Roesch, W. Lucht, and R. Dickinson, "MODIS bidirectional reflectance distribution function and albedo climate modeling grid products and the variability of albedo for major global vegetation types," Journal of Geophysical Research D: Atmospheres, vol. 110, no. 1, pp. 1-13, 2005.

[24] T. Matsui, A. Beltrán-Przekurat, R. A. Pielke Sr., D. Niyogi, and M. B. Coughenour, "Continental-scale multiobservation calibration and assessment of Colorado State University Unified Land Model by application of Moderate Resolution Imaging Spectroradiometer (MODIS) surface albedo," Journal of Geophysical Research: Biogeosciences, vol. 112, no. 2, 2007.

[25] G. Myhre and A. Myhre, "Uncertainties in radiative forcing due to surface Albedo changes caused by land-use changes," Journal of Climate, vol. 16, no. 10, pp. 1511-1524, 2003.
[26] M. G. Flanner, K. M. Shell, M. Barlage, D. K. Perovich, and M. A. Tschudi, "Radiative forcing and albedo feedback from the Northern Hemisphere cryosphere between 1979 and 2008," Nature Geoscience, vol. 4, no. 3, pp. 151-155, 2011.

[27] J. Perket, M. G. Flanner, and J. E. Kay, "Diagnosing shortwave cryosphere radiative effect and its 21st century evolution in CESM," Journal of Geophysical Research Atmospheres, vol. 119, no. 3, pp. 1356-1362, 2014.

[28] R. A. Pielke, G. Marland, R. A. Betts et al., "The influence of land-use change and landscape dynamics on the climate system: relevance to climate-change policy beyond the radiative effect of greenhouse gases," Philosophical Transactions of the Royal Society A: Mathematical, Physical and Engineering Sciences, vol. 360, no. 1797, pp. 1705-1719, 2002.

[29] A. Kleidon, “The climate sensitivity to human appropriation of vegetation productivity and its thermodynamic characterization," Global and Planetary Change, vol. 54, no. 1-2, pp. 109-127, 2006.

[30] J. G. Salomon, C. B. Schaaf, A. H. Strahler, F. Gao, and Y. Jin, "Validation of the MODIS Bidirectional Reflectance Distribution Function and albedo retrievals using combined observations from the Aqua and Terra platforms," IEEE Transactions on Geoscience and Remote Sensing, vol. 44, no. 6, pp. 1555-1564, 2006.

[31] IPCC, Climate Change 2007. The Physical Science Basis, Cambridge University Press, Cambridge, UK, 2007.

[32] NEESPI, The Northern Eurasia Earth Science Partnership Initiative (NEESPI) Executive Overview, NEESPI Science Plan Development Team, 2004.

[33] S. R. Helfrich, D. McNamara, B. H. Ramsay, T. Baldwin, and T. Kasheta, "Enhancements to, and forthcoming developments in the Interactive Multisensor Snow and Ice Mapping System (IMS)," Hydrological Processes, vol. 21, no. 12, pp. 1576-1586, 2007.

[34] T. W. Estilow, A. H. Young, and D. A. Robinson, "A long-term Northern Hemisphere snow cover extent data record for climate studies and monitoring," Earth System Science Data, vol. 7, no. 1, pp. 137-142, 2015.

[35] L. C. Brown, S. E. L. Howell, J. Mortin, and C. Derksen, "Evaluation of the Interactive Multisensor Snow and Ice Mapping System (IMS) for monitoring sea ice phenology," Remote Sensing of Environment, vol. 147, pp. 65-78, 2014.

[36] C. Derksen and R. Brown, "Spring snow cover extent reductions in the 2008-2012 period exceeding climate model projections," Geophysical Research Letters, vol. 39, no. 19, 2012.

[37] K. A. Scott, M. Buehner, A. Caya, and T. Carrieres, "A preliminary evaluation of the impact of assimilating AVHRR data on sea ice concentration analyses," Remote Sensing of Environment, vol. 128, pp. 212-223, 2013.

[38] T. Liu, S. Zhang, X. Xu, K. Bu, J. Ning, and L. Chang, "High resolution land cover datasets integration and application based on Landsat and Globcover data from 1975 to 2010 in Siberia," Chinese Geographical Science, vol. 26, no. 4, pp. 429-438, 2016.

[39] H. D. Kambezidisa, D. G. Kaskaoutisa, G. K. Kalliampakosb, A. Rashkic, and M. Wildd, "The solar dimming/brightening effect over the mediterranean basin in the period 1979-2012," Journal of Atmospheric and Solar-Terrestrial Physics, vol. 150, pp. 31-46, 2016.

[40] L. Zhou, R. E. Dickinson, Y. Tian et al., "Comparison of seasonal and spatial variations of albedos from moderate-resolution imaging spectroradiometer (modis) and common land model," 
Journal of Geophysical Research: Atmospheres, vol. 108, no. 15, 2003.

[41] G. Myhre, M. M. Kvalevåg, and C. B. Schaaf, "Radiative forcing due to anthropogenic vegetation change based on MODIS surface albedo data," Geophysical Research Letters, vol. 32, no. 21, 2005. 

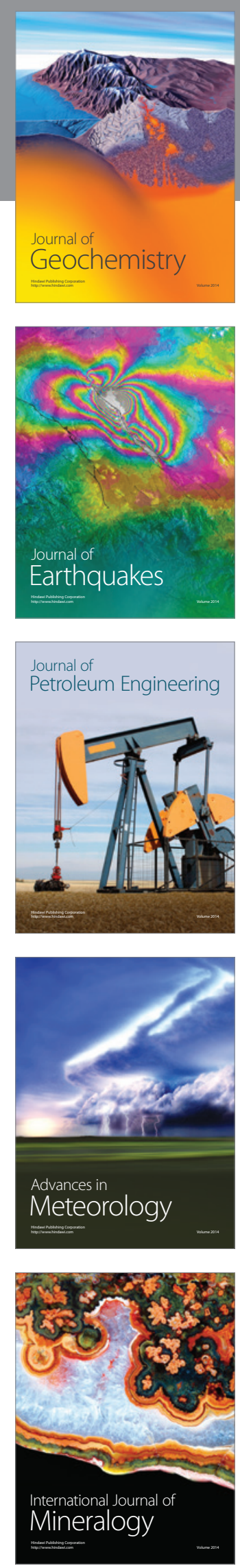
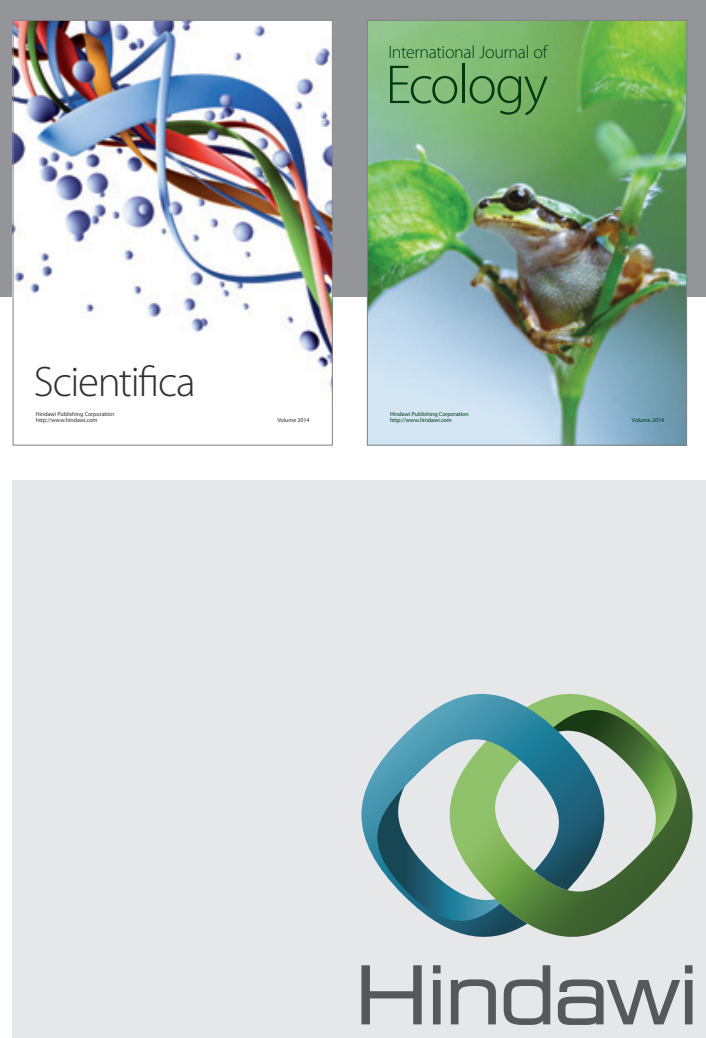

Submit your manuscripts at

https://www.hindawi.com
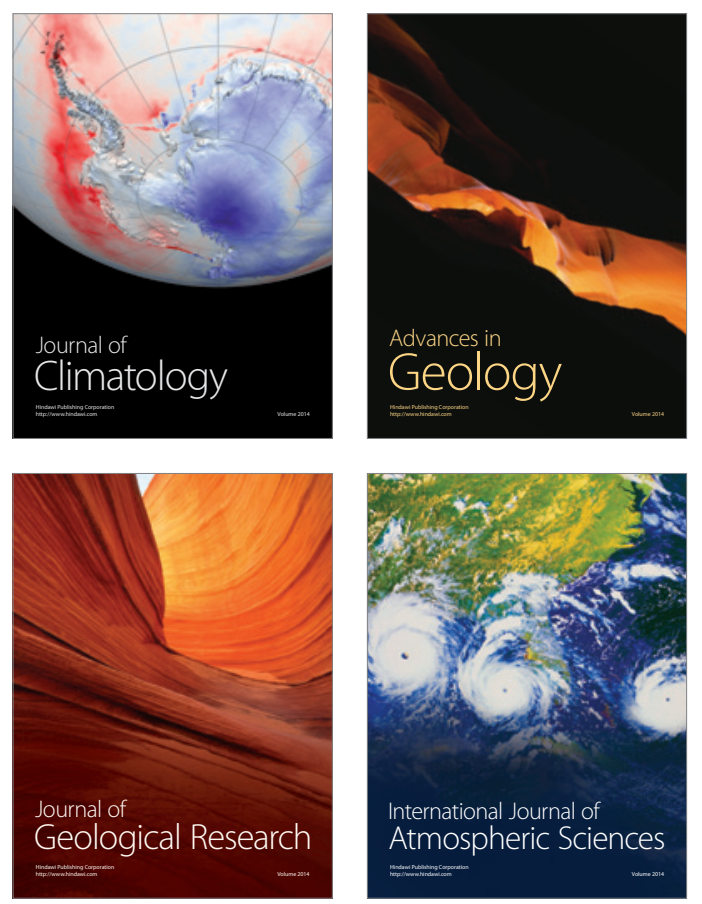

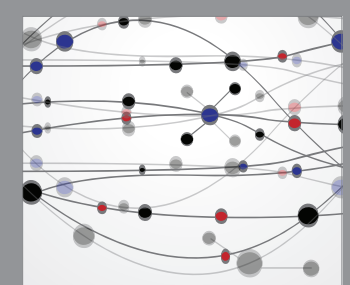

The Scientific

\section{World Journal}
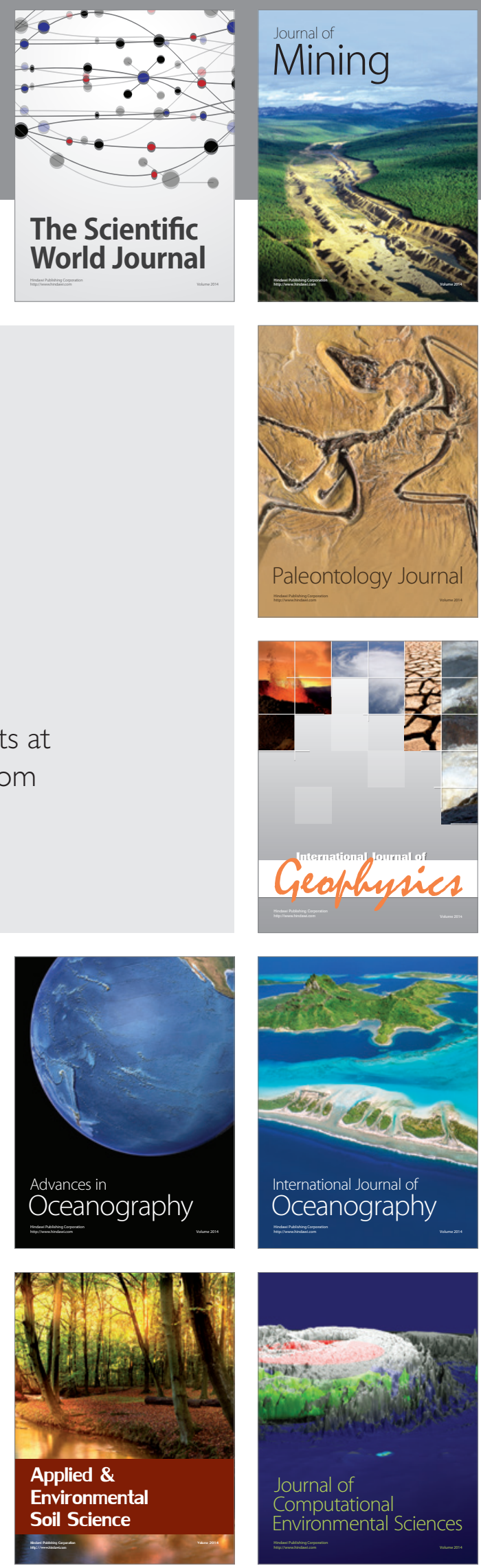